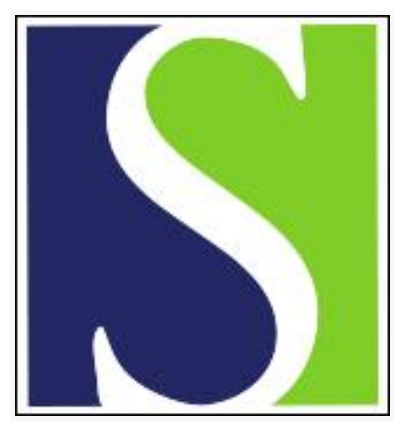

Scand J Work Environ Health 1999;25(1):24-32

https://doi.org/10.5271/sjweh.379

Issue date: Feb 1999

\title{
Genotoxic exposures of potroom workers
}

by Carstensen U, Yang K, Levin J-O, Östman C, Nilsson T, Hemminki K, Hagmar L

The following article refers to this text: 2008;34(6):463-470

Key terms: aluminum reduction plant; biological monitoring; peripheral lymphocyte; personal airborne sampling; urinary metabolite

This article in PubMed: www.ncbi.nlm.nih.gov/pubmed/10204667

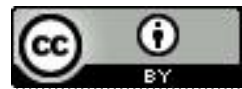




\title{
Genotoxic exposures of potroom workers
}

\author{
by Ulrica Carstensen, MD, ${ }^{1}$ Ke Yang, PhD, ${ }^{2}$ Jan-Olof Levin, PhD, ${ }^{3}$ Conny Östman, PhD, ${ }^{4}$ Tohr Nilsson, \\ $M D,{ }^{5}$ Kari Hemminki, MD, ${ }^{2}$ Lars Hagmar, $M D^{6}$
}

\begin{abstract}
Carstensen U, Yang K, Levin J-0, Östman C, Nilsson T, Hemminki K, Hagmar L. Genotoxic exposures of potroom workers. Scand J Work Environ Health 1999;25(1):24-32.

0bjectives Potroom workers in aluminum reduction plants have increased risks for bladder and lung cancer due to exposure from polycyclic aromatic hydrocarbons (PAH). In this study correlations between measures of the external, internal, and biological effective dose have been studied for PAH.

Methods Venous blood samples were obtained from 98 male potroom workers and 55 unexposed male blue-collar workers, for the analysis of aromatic adducts to DNA (deoxyribonucleic acid) in lymphocytes, using the ${ }^{32}$ Ppostlabeling technique. 1-Hydroxypyrene in urine was analyzed with high-pressure liquid chromatography. Personal sampling of both particulate and gas phase $\mathrm{PAH}$ was performed during a full workday for the potroom workers and for 5 referents. Individual PAH congeners were determined with liquid chromatographic-mass spectrometric and gas chromatographic-mass spectrometric techniques.

Results The respiratory-zone airborne level of the sum of 22 particulate (median $13.2 \mu \mathrm{g} / \mathrm{m}^{3}$ ) and the 7 gas phase PAH-congeners (median $16.3 \mu \mathrm{g} / \mathrm{m}^{3}$ ) among the potroom workers was a hundred times higher than among the referents. The urinary concentration of 1-hydroxypyrene before work was 30 times higher for the potroom workers (median $3.43 \mu \mathrm{mol} / \mathrm{mol}$ creatinine) than for the referents. Most airborne PAH congeners correlated with the excretion of 1-hydroxypyrene in urine. The frequency of aromatic DNA adducts did not, however, differ between the potroom workers and the referents, and no correlation was found for 1-hydroxypyrene in urine.

Conclusions Despite an obvious occupational exposure to PAH, no increase in aromatic DNA adducts in lymphocytes was found among the potroom workers.
\end{abstract}

Key terms aluminum reduction plant, biological monitoring, peripheral lymphocytes, personal airborne sampling, urinary metabolites.

In aluminum production plants using the Söderberg vertical stud process, a casing filled with coal tar is used as an anode. This process has previously caused high airborne exposure levels of coal tar pitch volatiles, containing polycyclic aromatic hydrocarbons (PAH) (1). Potroom workers have increased risks for both bladder and lung cancer ( $2-4)$, probably due to the PAH exposure. Due to technical improvements in the plants, the airborne exposure levels have, however, been reduced during recent years.

For an adequate risk assessment of potroom work, data on PAH levels in the breathing zone have to be supplemented with other surveillance data. The use of personal respiratory protection devices and the possibility of a dermal uptake of PAH (5) calls for the use of a biomarker of internal dose. Pyrene is one of the main components in coal tar, and about $90 \%$ of human uptake is excreted in urine as 1-hydroxypyrene (6). Recently, 1-hydroxypyrene in urine has been utilized for the biological monitoring of occupational PAH exposure in coke plants $(5,7-9)$, aluminum plants $(10,11)$, creosote impregnation plants $(12,13)$, tar distillation plants (6), and road paving $(14,15)$.

The initial mechanistic step in PAH-induced carcinogens is the binding of PAH metabolites to DNA (deoxyribonucleic acid) in bronchial and urine bladder

1 Department of Occupational and Environmental Medicine, University Hospital of Northern Sweden, Umeå, Sweden.

2 Center for Nutrition and Toxicology, Karolinska Institute, Sweden.

3 National Institute of Working Life, Analytical Chemistry Division, Umeå, Sweden.

4 Department of Analytical Chemistry, Stockholm University, Stockholm, Sweden.

5 Department of Occupational and Environmental Medicine, Sundsvall Hospital, Sundsvall, Sweden.

6 Department of Occupational and Environmental Medicine, Lund University Hospital, Lund, Sweden.

Reprint requests to: Dr Lars Hagmar, Department of Occupational and Environmental Medicine, Lund University Hospital, S22185 Lund, Sweden. [E-mail: Lars.Hagmar@ymed.lu.se] 
epithelium (1). There is currently no technique available for directly assessing such exposure in these target organs. The ${ }^{32} \mathrm{P}$-postlabeling technique for estimating aromatic adducts to DNA has been employed for potroom workers, peripheral white blood cells being used as the surrogate tissue $(16-19)$. Total counts of white blood cells are not optimal, however, for adduct studies due to the predominance of short-lived granulocytes (20). It is more relevant to assess the effect of long-term exposure to $\mathrm{PAH}$ in peripheral lymphocytes which have a longer mean half-time.

The aim of the present study was to assess the congener-specific airborne $\mathrm{PAH}$ exposure in the breathing zone, the urinary excretion of 1-hydroxypyrene, and the aromatic adducts to DNA in peripheral lymphocytes of potroom workers and unexposed referents, and to evaluate the respective correlations between these measures of external, internal, and biological effective dose.

\section{Subjects and methods}

\section{Plant}

The study was performed in a Swedish aluminum primary production plant built in 1963, in which the Söderberg vertical stud process was used. The electrolysis plant consisted of 2 potrooms, 680 and $790 \mathrm{~m}$ long, with a total of 262 electrolytic cells. In 1975 a change from the use of liquid to solid coal tar was made in this plant to reduce the emissions of PAH. Personal measurements of airborne benzo[a]pyrene in the same plant a few years before the present study ranged from 1.9 to $36 \mu \mathrm{g} / \mathrm{m}^{3}$, with a median of $2.8 \mu \mathrm{g} / \mathrm{m}^{3}$ (21). Besides PAH, the plant also has exposure to alumina, cryolite, carbon monoxide, fluorides, hydrogen fluoride (especially in hall A), and static electromagnetic fields.

Aluminum metal is produced by electrolytic reduction of alumina $\left(\mathrm{Al}_{2} \mathrm{O}_{3}\right)$ into aluminum in electrolytic cells (pots) at a low voltage (about $4-6 \mathrm{~V}$ ). As alumina has a very high melting point (about $2000^{\circ} \mathrm{C}$ ), cryolite $\left(\mathrm{NA}_{3} \mathrm{AlF}_{6}\right)$ is used as a dissolving material. Cryolite is melted at a temperature below $1000^{\circ} \mathrm{C}$. The carbon lining of the pot serves as the cathode and a casing filled with coal tar, above the pot, as the anode. The anode is baked by the heat produced by the passage of the electric current.

\section{Study population}

The selection of the 98 potroom workers in the final study population is presented in figure 1 . All but one were Caucasians. Twelve worked days and 86 worked shifts (8hour shifts). Their median age was 35 (range 22-60) years, and the median overall employment time was 84 (range 16-386) months. All the subjects were interviewed by a physician (UC) with respect to present health, medical history, smoking habits, alcohol consumption, earlier employment, and use of personal protection devices.

\section{Referents}

Altogether 55 male blue-collar workers (mail carriers and city council employees) from the same town as the smelter were recruited as referents. They were interviewed by the same physician who interviewed the potroom workers. None of the referents had been occupationally exposed to PAH during the preceding 5 years. Their median age was 41 (range $22-61$ ) years.

\section{Smoking habits and medical history}

Thirty-one percent of the potroom workers were current smokers (at least 1 cigarette/day, $1 \mathrm{~g}$ of pipe tobacco was considered equivalent to 1 cigarette), as compared with $22 \%$ of the referents. Three of the smelter workers and 2 of the referents had had the flu during the preceding year. Fifty-three percent of the smelter workers and $65 \%$ of the referents had gone through some type of radiographic examination (mainly dental $\mathrm{X}$-ray) during the preceding year.

\section{Work habits and protection devices}

At the time of examination, 93 of the smelter employees had continuously worked in the smelter during the last 6 months, and the remaining 5 subjects had worked there only the last 3 months. The estimated median fraction of worktime spent in the proximity of the furnaces was 55 (10th centile 38,90 th centile 70 )\% for the potroom

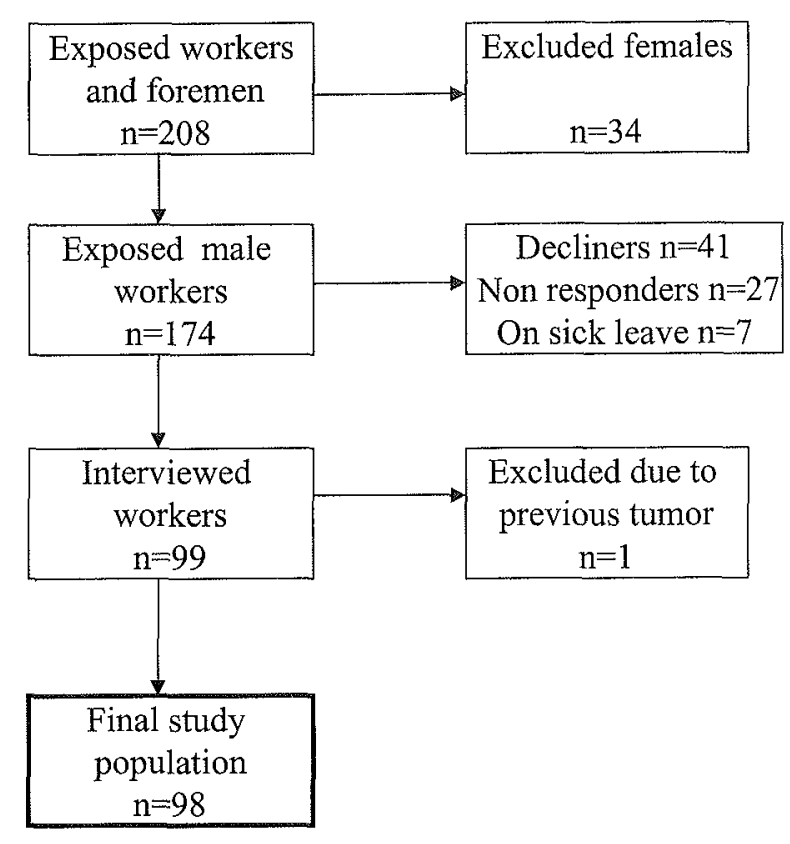

Figure 1. Flow chart of the selection of the exposed study population. 
workers. Sixty-two percent of the potroom workers were using effective personal respiratory protection devices, and $38 \%$ used them only when they suspected that their work task might lead to high PAH exposure. The use of respiratory protection devices had increased during the months preceding the examination, due to the policy of the plant. All the potroom workers used protective gloves and took a shower immediately after work.

\section{Venous blood sampling}

Venous blood samples were obtained in the morning, during an 8-week period. Samples were in most cases drawn from both the potroom workers and the referents during the same mornings. The shift workers were sampled on the second or third workday morning after a preceding 6-day work leave. Blood samples were collected in heparinized Vacutainer CPT ${ }^{\mathrm{TM}}$ tubes. Within 1.5 hours of the sampling, the tubes were gently inverted 8 times prior to centrifugation for 20 minutes in a horizontal rotor with a cooling system, at $1500 \mathrm{~g}$ and $20^{\circ} \mathrm{C}$. The centrifugation separated the mononuclear cells. The tubes were transported by air freight in cold boxes and reached the laboratory within 6 hours of the sampling.

\section{Urine sampling}

For the shift workers urine samples were collected in the morning before the shift, and in the late evening after the shift, on the 6th workday. For the daytime potroom workers, the urine samples were collected in the morning before work and in the afternoon after work, on the 4 th or 5 th workday of the week. For the referents urine samples were collected on the same morning as the blood samples were drawn. Urine samples were also collected after work from the 5 referents for whom the airborne levels of PAH in the respiratory zone were measured.

\section{Sampling and analysis of airborne polycyclic aromatic hydrocarbons}

Personal sampling of both the particulate and gas phase PAH was performed during a full workday for the potroom workers and for 5 subjects randomly selected from the reference group.

The personal sampler unit consisted of a battery-operated personal sampler pump (224-PCXR7, SKC Inc., Eighty Four, PA, USA) and a cylindrical sampler constructed from anodized aluminum (22). The sampler had an overall length of $65 \mathrm{~mm}$, a maximum diameter of 32 $\mathrm{mm}$, and a weight of $45 \mathrm{~g}$. It contained a $25-\mathrm{mm}$ binderfree, A/E glass-fiber filter (Gelman Sciences Inc., Ann Arbor, MI, USA) in series with 2 cylindrical polyurethane foam (PUF) plugs $15 \mathrm{~mm}$ in diameter and 15 $\mathrm{mm}$ in length (Specialplast AB, Gillinge, Sweden). The filter and PUF plugs trapped the particulate and the semivolatile associated PAH fractions, respectively. The second PUF plug was used to check the break-through of
PAH in the sampler. In all cases the break-through was $<4 \%$ for phenanthrene, $<2 \%$ for pyrene, and not detectable at all for benzo[a]pyrene (B[a]P). The sampling time was around 400 minutes at a flow of $1.51 / \mathrm{min}$. The flow through the sampler was measured both prior to the sampling and after the sampling procedure.

PAH were analyzed using a method developed by Östman et al (23). Both the filter and adsorbent were Soxhlet-extracted with $10 \mathrm{ml}$ of dichloromethane for 16 hours. Approximately $10 \%$ of the extract was preseparated on a column (inner diameter $6 \mathrm{~mm}$, length $60 \mathrm{~mm}$ ) packed with silica (Kiselgel 60, 0.06-0.2 mm, Merck, Germany), which had been heated to $450^{\circ} \mathrm{C}$ for 24 hours in a gentle stream of nitrogen and subsequently deactivated with $10 \%$ (wet weight) of water. Aliphatic, alicyclic, olefinic, and aromatic compounds were eluted with $8 \mathrm{ml}$ of cyclohexane. The solvent volume was reduced to $1 \mathrm{ml}$ by using a gentle stream of nitrogen $(\mathrm{g})$, and an aliquot of that volume, $0.1 \mathrm{ml}$, was subsequently analyzed using a coupled liquid chromatography - gas chromatography (LC-GC) setup (22) consisting of a Varian 9001 LC pump (Varian Associates, Walnut Creek, CA, USA), a Hitachi L4000 ultraviolet detector (Merck-Hitachi, Germany) set at $254 \mathrm{~nm}$, a loop interface (22), and a Varian 3700 GC equipped with a flame ionization detector. The PAH fraction was isolated with the LC system utilizing a nitropropyl silica column $(4.0 \times 75 \mathrm{~mm}$, $5 \mathrm{~mm}$ Nucleosil- $\mathrm{NO}_{2}$, Macherey-Nagel, D, Germany) and applying a back-flush technique. On-line transfer of the $\mathrm{PAH}$ fraction to the GC system was made using the looptype interface. Subsequent GC analysis was made using a capillary column with an inner diameter of $28 \mathrm{~m} \times 0.32$ $\mathrm{mm}$ (DB-5, $0.25 \mathrm{~mm} 5 \%$ phenylmethylsiloxane gum, J\&W Scientific, Folsom, CA, USA). Up to 22 PAH components were quantified in each sample with a detection limit of about $0.1 \mathrm{ng}$. Standards for all the nonmethylated PAH congeners have been included in each analytical series. The absolute recovery for the analytical method was about 90-95\%. Gas chromatography - mass spectrometry (GC-MS) was used to verify the identity of the detected PAH components in some of the selected samples.

\section{Analysis of 1-hydroxypyrene in urine}

Urine was submitted to enzymatic hydrolysis and cleanup according to Jongeneelen et al (6). Samples were analyzed by high-pressure liquid chromatography (HPLC) with fluorescence detection, and 1-hydroxypyrene was detected at an excitation wavelength of $242 \mathrm{~nm}$ and an emission wavelength of $388 \mathrm{~nm}$ (21). The detection limit, as 3 times the standard deviation of the noise, was 0.04 $\mathrm{ng} / \mathrm{ml}$. To account for differences in the dilution of the urine, the urinary 1-hydroxypyrene concentrations in urine were corrected for creatinine, which was analyzed by a routine technique. 


\section{DNA isolation from lymphocytes}

The lymphocyte pellet was washed in $10 \mathrm{ml}$ of buffer [0.15 M sodium chloride, $10 \mathrm{mM}$ tris(hydroxylmethyl)aminomethane (Tris), $\mathrm{pH} 7.4$ ] and retrieved by centrifuging at $2000 \mathrm{revolutions} / \mathrm{min}$ for $10 \mathrm{~min}$. The cell pellet was resuspended in $1.3 \mathrm{ml}$ of $50 \mathrm{mM}$ Tris buffer ( $\mathrm{pH} 7.4$ ), $100 \mu \mathrm{l}$ of $10 \%$ Triton $\mathrm{X}-100$ (polyethylene glycol p-isooctylphenyl ether) was added, and the cell pellet was placed on ice for $5 \mathrm{~min}$ to lyse the cell membrane. Crude nuclei were isolated by centrifugation (13000 revolutions/min, $5 \mathrm{~min}$ ). To degrade RNA (ribonucleic acid), 5 $\mu \mathrm{l}$ of ribonuclease $\mathrm{A}(10 \mu \mathrm{g} / \mu \mathrm{l})$ and $2 \mu \mathrm{l}$ of RNase $\mathrm{T} 1$ $(20 \mathrm{U} / \mu \mathrm{l})$ were added after the nuclei were suspended in $0.5 \mathrm{ml}$ of $50 \mathrm{mM}$ Tris (pH 8.0), followed by incubation at $37^{\circ} \mathrm{C}$ for 1 hour. Then $250 \mu \mathrm{l}$ of $50 \mathrm{mM}$ Tris ( $\mathrm{pH} 8.0$ ), $85 \mu \mathrm{l}$ of $100 \mathrm{mM}$ calcium chloride and $500 \mu \mathrm{g}$ of proteinase $\mathrm{K}(10 \mathrm{mg} / \mathrm{ml})$ were added, and incubation was continued overnight to degrade protein. The solution was extracted sequentially with an equal volume of phenol (preequilibrated with $0.1 \mathrm{M}$ Tris, $\mathrm{pH} 8.0$ ), phenol:sevag (chloroform/isoamyl alcohol, 24:1), 1:1, and sevag. DNA was precipitated from the aqueous phase by adding a 0.1 volume of $5 \mathrm{M}$ sodium chloride, and 1 volume of chilled ethanol, followed by centrifugation (13000 revolutions/ $\mathrm{min}, 5 \mathrm{~min}$ ). The DNA pellet was washed once with $70 \%$ ethanol and dissolved in Millipore water. After ultrasonic treatment of the DNA solution, the DNA concentration was determined by absorbance at $260 \mathrm{~nm}$ and DNA purity by the $A_{260 n m}: A_{280 m m}$ ratio, which ranged between 1.62 and 1.74. From our previous comparisons of measuring DNA by absorbance or by labeling the normal nucleotides, we assumed that no systematic error was introduced by the absorbance method.

\section{DNA digestion}

An aliquot of $5 \mu \mathrm{g}$ DNA in a $0.5-\mathrm{ml}$ Eppendorf tube was evaporated to dryness in a Speedvac. DNA was digested first by $3 \mu \mathrm{l}$ of mixture containing $2.0 \mu \mathrm{l}$ of micrococcal nuclease $(0.2 \mathrm{U} / \mu \mathrm{l}), 0.5 \mu \mathrm{l}$ of bicine buffer $(3 \mathrm{mM}, \mathrm{pH}$ 9.0 ) and $0.5 \mu 1$ of $0.5 \mathrm{mM}$ calcium chloride, and then by $3 \mu \mathrm{l}$ of a mixture containing $2.0 \mu \mathrm{l}$ of spleen phosphodiesterase $(4 \mathrm{mU} / \mu \mathrm{I})$ and $1.0 \mu \mathrm{l}$ of ammonium acetate $(20$ $\mathrm{mM}, \mathrm{pH} 5.0$ ). After each addition of the enzymes, the reaction was incubated at $37^{\circ} \mathrm{C}$ for 2 hours. The digested DNA solution was incubated with $1.0 \mu \mathrm{l}$ of nuclease $\mathrm{P} 1\left(5 \mu \mathrm{g} / \mu \mathrm{l}\right.$ in $1.5 \mathrm{mM}$ zinc chloride) at $37^{\circ} \mathrm{C}$ for $40 \mathrm{~min}$ utes. The solution was evaporated to dryness. Water $(1.0$ $\mu l)$ was added to the tube just before the postlabeling reaction. The completeness of the DNA digestion was checked by analyzing a parallel sample for nucleoside concentration by HPLC (24).

\section{${ }^{32}$ p-postlabeling}

When postlabeling the adducts, we used a $1.0 \mu \mathrm{lmix}-$ ture containing $0.2 \mu \mathrm{l}$ of T4 polynucleotide kinase (T4
PNK) buffer (400 mM bicine, $200 \mathrm{mM}$ dithiothreitol, 200 $\mathrm{mM}$ magnesium chloride, $20 \mathrm{mM}$ spermidine, $\mathrm{pH}$ 9.6), $0.08 \mu \mathrm{l}$ of T4 PNK $(30 \mathrm{U} / \mu \mathrm{l}), 0.7 \mu \mathrm{l}$ of $\left[\mathrm{g}{ }^{32} \mathrm{P}\right] \mathrm{ATP}$ (specific activity $3000 \mathrm{Ci} / \mathrm{mM}, 10 \mu \mathrm{Ci} / \mu \mathrm{l}$ ) and $0.02 \mu \mathrm{l}$ of water. The total volume of the reaction was $2.0 \mu \mathrm{l}$. The reaction proceeded at $37^{\circ} \mathrm{C}$ for 30 minutes; $1.0 \mu 1$ apyrase $(30 \mathrm{mU} / \mu \mathrm{l})$ was added to degrade extra $\left[\mathrm{g}^{32} \mathrm{P}\right] \mathrm{ATP}$ at $37^{\circ} \mathrm{C}$ for 15 minutes after the postlabeling reaction. BPDE-dGMP was used as a positive control and a mixture of the DNA-hydrolyzing solutions without DNA served as a negative control in each experiment. HPLC was used to check that an excess of ATP (adenosine triphosphate) remained in the assay (24). An aliquot was taken for analysis before apyrase was added.

The solution $(3.0 \mu \mathrm{l})$ was transferred to a polyethylene imine (PEI) cellulose thin-layer chromatographic (TLC) plate (Macherey-Nagel). The DNA adducts were then resolved according to Yang et al (25) with modifications. The chromatographic solvents used were as follows: 1.0 M sodium phosphate ( $\mathrm{pH}$ 6.0) in D1, 3.6 M lithium formate, $8.5 \mathrm{M}$ urea $(\mathrm{pH} 3.5)$ in $\mathrm{D} 3$, and $0.8 \mathrm{M}$ lithium chloride, 0.5 M Tris, 8.5 M urea (pH 8.0) in D4. A $2.7-\mathrm{cm}$ Whatman 17 paper wick was stapled on the TLC plate in the development of D4 to remove the frontier background. Screen-intensified autoradiography was carried out at $-86^{\circ} \mathrm{C}$ for 3 days. Adduct spots were cut as shown in figure 2 and analyzed for radioactivity by Cerenkov counting. The radioactivity of the same area in the negative control plate was used as the background value in the calculations of the adduct levels.

The DNA adduct level was determined at least twice for each sample. The variation was less than $30 \%$ for most $(65 \%)$ of the samples. The mean value of several determinations was used to represent the adduct level of each sample.

\section{Statistical methods}

For comparing two independent groups of observations by significance testing, we used the Mann-Whitney's Utest for continuous variables. The association between the use of respiratory protection devices (expressed as a categorical variable) and the 1-hydroxypyrene concentrations in urine, and the PAH-DNA adducts in peripheral lymphocytes, respectively, were assessed by means of Joncheere-Terpstra's test. Correlations were determined by Spearman's rank correlation test. The P-values reported are 2 -sided

\section{Results}

The respiratory-zone airborne level of the sum of 22 particulate PAH congeners ranged between 0.01 and 270 (median 13.2) $\mathrm{\mu g} / \mathrm{m}^{3}$, for a full workday in the 

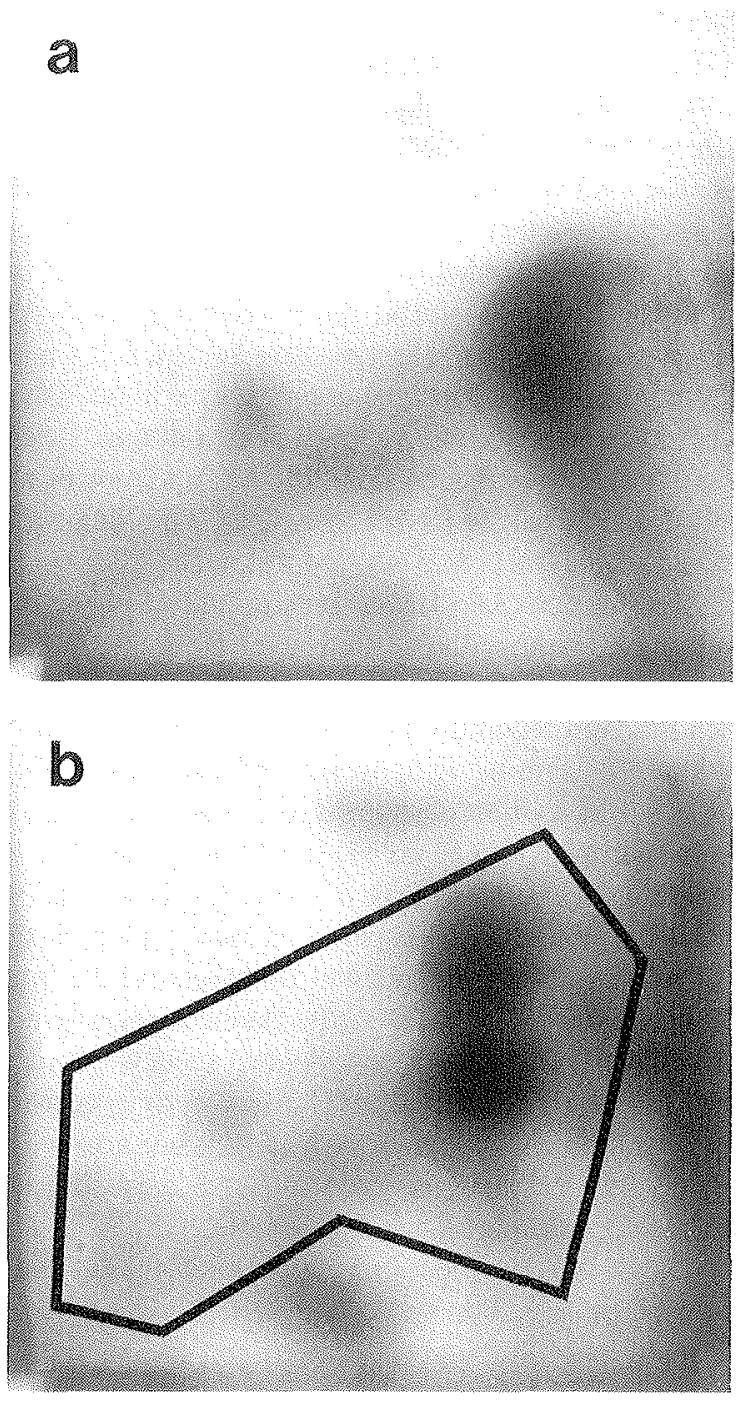

c

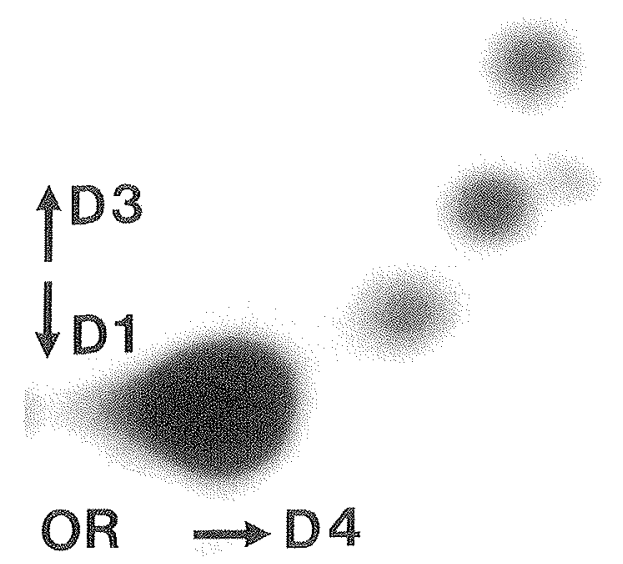

Figure 2. Autoradiograms of DNA adduct patterns from an unexposed (a) and exposed (b) smoker, and from the BPDE standard (c). Panel b shows the area of the plate used for counting radioactivity. Panel $c$ shows the origin and directions of the chromatography. $(O R=$ origin of application, DNA = deoxyribonucleic acid) aluminum potroom, as compared with 0.01 to 0.37 (median 0.11$) \mu \mathrm{g} / \mathrm{m}^{3}$ for 3 occupationally unexposed referents (table 1). The air samples from the remaining 2 referents contained no PAH congener levels above the detection limits. The median concentration of $\mathrm{B}[\mathrm{a}] \mathrm{P}$ among the potroom workers was 1 (range $0.02-24) \mu \mathrm{g} / \mathrm{m}^{3}$, as compared with 0.004 and $0.02 \mu \mathrm{g} / \mathrm{m}^{3}$ for the 2 referents with measurable levels.

The respiratory-zone concentrations of the sum of 7 gas phase PAH congeners varied for the potroom workers between 0.01 and 131 (median 16.3 ) $\mu \mathrm{g} / \mathrm{m}^{3}$ as compared with 0.008 to 0.41 (median 0.20 ) for the occupationally unexposed referents (table 2).

The urinary concentration of 1-hydroxypyrene sampled immediately before work varied between 0.07 and 26.6 (median 3.43) $\mu \mathrm{mol} / \mathrm{mol}$ creatinine for the potroom workers and between 0.02 and 0.99 (median 0.11) $\mu \mathrm{mol} /$ mol creatinine for the referents (table 3 ). Among the potroom workers the concentrations of 1-hydroxypyrene in urine were significantly higher immediately after work (median $4.31 \mu \mathrm{mol} / \mathrm{mol}$ creatinine) than before work $(\mathrm{P}=0.002)$. The interindividual change in excretion over the workday, was, however, substantial (range -24.7 to $7.80 \mu \mathrm{mol} / \mathrm{mol}$ creatinine).

Table 1. Time-weighted average exposure to particulate polycyclic aromatic hydorcarbons (PAH) $\left(\mathrm{mg} / \mathrm{m}^{3}\right)$ in the respiratory zone during a full workday of the potroom workers and the referents.

\begin{tabular}{|c|c|c|c|c|c|}
\hline \multirow[t]{2}{*}{$\mathrm{PAH}$} & \multicolumn{2}{|c|}{ Potroom workers } & \multicolumn{3}{|c|}{ Referents } \\
\hline & N Median & Range & N & Median & Range \\
\hline Phenanthrene & 850.23 & $0.05-11.8$ & 2 & & $0.003-0.01$ \\
\hline Anthracene & $48 \quad 0.09$ & $0.01-3.05$ & - & & .. \\
\hline 1-Methylphenanthrene & $\begin{array}{ll}58 & 0.03\end{array}$ & $0.01-1.02$ & 2 & & $0.003-0.003$ \\
\hline 2-Methylphenanthrene & $\begin{array}{ll}58 & 0.1\end{array}$ & $0.03-1.81$ & 2 & & $0.004-0.004$ \\
\hline 3-Methylphenanthrene & $\begin{array}{ll}58 & 0.08\end{array}$ & $0.03-1.22$ & 2 & & $0.003-0.003$ \\
\hline $\begin{array}{l}\text { 9+4-Methyl- } \\
\text { phenanthrene }\end{array}$ & 580.08 & $0.03-1.22$ & 2 & & $0.002-0.002$ \\
\hline Fluoranthene & 941.24 & $0.02-32.9$ & 3 & 0.01 & $0.005-0.05$ \\
\hline Pyrene & 941.11 & $0.02-34.4$ & 3 & 0.02 & $0.005-0.05$ \\
\hline 1-Methylpyrene & 920.09 & $0.01-2.56$ & 2 & & $0.004-0.008$ \\
\hline 2-Methylpyrene & 870.08 & $0.01-1.34$ & 2 & & $0.001-0.002$ \\
\hline Benzo(a)fluorene & 930.26 & $0.05--5.73$ & 2 & & $0.003-0.008$ \\
\hline 4-Methy|pyrene & 920.10 & $0.02-2.45$ & 2 & & $0.006-0.006$ \\
\hline Benz(a)anthracene & 941.42 & $0.11-22.6$ & 2 & & $0.007-0.04$ \\
\hline Chrysene/triphenylene & 942.49 & $0.27-26.0$ & 2 & & $0.01-0.05$ \\
\hline Benzo $(a+b)$ fluoranthene & 942.38 & $0.28-26.0$ & 2 & 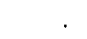 & $0.007-0.04$ \\
\hline Benzo $(j+k)$ fluoranthene & 940.86 & $0.15-10.9$ & 2 & & $0.003-0.02$ \\
\hline Benzo(e)pyrene & 941.50 & $0.17-18.3$ & 2 & & $0.004-0.02$ \\
\hline Benzo(a)pyrene & $93 \quad 0.97$ & $0.02-23.5$ & 2 & . & $0.004-0.02$ \\
\hline Perylene & $93 \quad 0.23$ & $0.01-6.14$ & 2 & & $0.001-0.004$ \\
\hline Indeno(1,2,3-cd)pyrene & 940.63 & $0.06-14.6$ & 2 & . & $0.004-0.01$ \\
\hline Picene & $90 \quad 0.15$ & $0.03-2.11$ & 1 & 0.005 & .. \\
\hline Benzo(ghi)perylene & $94 \quad 0.77$ & $0.08-23.6$ & 2 & ' & $0.008-0.01$ \\
\hline & 9713.2 & $0.01-270$ & 3 & 0.11 & $0.01-0.37$ \\
\hline
\end{tabular}


Smoking referents had higher concentrations of 1-hydroxypyrene in their morning urine (median 0.17 , range $0.09-0.99 \mu \mathrm{mol} / \mathrm{mol}$ creatinine) than nonsmoking referents (median 0.10 , range $0.02-0.50, P=0.0005$ ). The exposed workers who were smokers did not differ from their nonsmoking colleagues with respect to the excretion of 1-hydroxypyrene in urine $(\mathrm{P}>0.5)$.

Airborne particulate pyrene showed a statistically significant, but moderately strong correlation $\left(r_{s}=0.34\right)$, with the change in the excretion of 1-hydroxypyrene in urine over the same workday (table 4 ). All but 4 of the other $\mathrm{PAH}$ congeners in the particulate phase were also significantly correlated with the excretion of 1-hydroxypyrene in urine. All 7 PAH congeners in the gaseous phase also correlated significantly with the excretion of 1 -hydroxypyrene in urine (table 5). It is noteworthy that the weakest correlation observed for these congeners was for airborne pyrene. The potroom workers who stated that they always used respiratory protection had as a median somewhat lower concentrations of 1-hydroxypyrene in their morning urine as compared with the other potroom workers $(\mathrm{P}=0.06$ ) (table 6).

DNA adducts were analyzed by the postlabeling assay. Typical autoradiograms are shown in figure 2 , which

Table 2. Time-weighted average exposure to gaseous phase polycyclic aromatic hydrocarbons ( $\mathrm{PAH})\left(\mu \mathrm{g} / \mathrm{m}^{3}\right)$ in the respiratory zone during a full workday the potroom workers and the referents.

\begin{tabular}{|c|c|c|c|c|c|}
\hline \multirow[t]{2}{*}{$\mathrm{PAH}$} & \multicolumn{2}{|c|}{ Potroom workers } & \multicolumn{3}{|c|}{ Referents } \\
\hline & N Median & Range & N & Median & Range \\
\hline Phenanthrene & 949.14 & $1.75-73.8$ & 4 & 0.11 & $0.04-0.22$ \\
\hline Anthracene & 931.10 & $0.04-12.3$ & 4 & 0.01 & $0.002-0.02$ \\
\hline 2-Methylphenanthrene & 940.61 & $0.13-5.51$ & 4 & 0.02 & $0.005-0.02$ \\
\hline 3-Methylphenanthrene & 940.61 & $0.12-42.8$ & 4 & 0.02 & $0.005-0.02$ \\
\hline $\begin{array}{l}\text { 9+4-Methyl- } \\
\text { phenanthrene }\end{array}$ & $94 \quad 0.51$ & $0.07-4.23$ & 4 & 0.01 & $0.03-0.02$ \\
\hline Fluoranthene & 942.44 & $0.35-33.2$ & 5 & 0.03 & $0.005-0.06$ \\
\hline Pyrene & $95 \quad 1.56$ & $0.01-9.52$ & 5 & 0.03 & $0.003-0.04$ \\
\hline Sum & 9616.3 & $0.01-131$ & 5 & 0.20 & $0.008-0.41$ \\
\hline
\end{tabular}

Table 3. 1-Hydoxypyrene concentrations in urine $(\mu \mathrm{mol} / \mathrm{mol}$ creatinine) immediately before and after a full workday for the potroom workers and the referents.

\begin{tabular}{|c|c|c|c|c|c|c|}
\hline & \multicolumn{3}{|c|}{ Potroom workers } & \multicolumn{2}{|r|}{ Referents } & \multirow[t]{2}{*}{ P-value } \\
\hline & $N$ & Median & Range & $N$ & Median Range & \\
\hline Before work & 94 & $3.43^{a}$ & $0.07-26.6$ & 54 & $0.11 \quad 0.02-0.99$ & $<0.0001$ \\
\hline After work & 96 & 4.31 & $0.09-17.7$ & 5 & $0.130 .06-0.75$ & $<0.0001$ \\
\hline $\begin{array}{l}\text { Change in } \\
\text { excretion } \\
\text { over the }\end{array}$ & & & & & & \\
\hline workday & 93 & 0.77 & $-24.7-7.80$ & & . & \\
\hline
\end{tabular}

a $\mathrm{P}=0.002$ for the comparison of 1 -hydoxypyrene in urine before and after work for the potroom workers. revealed no consistent changes between the exposed workers and the referents. The level of PAH-DNA adducts in peripheral lymphocytes did not differ between the potroom workers (median 2.62 per $10^{8}$ nucleotides, range $1.44-6.67$ ) and referents (median 2.4, range $1.28-6.88$ ) (table 7). Neither smoking habits nor the use of respiratory protection devices at work affected the adduct levels (tables 6 and 7). Moreover, no correlations between age, length of exposure, or 1-hydroxypyrene in urine and PAH-DNA adducts were seen (data not shown).

Table 4. Correlations $\left(\mathrm{r}_{s}\right)$ among the potroom workers between particulate polycyclic aromatic hydrocarbons (PAH) $\left(\mathrm{mg} / \mathrm{m}^{3}\right)$ in the respiratory zone during a full workday and 1-hydroxypyrene in urine ( $\mathrm{mmol} / \mathrm{mol}$ creatinine) sampled after work, during the same workday.

\begin{tabular}{llrr}
\hline PAH & $N$ & $r_{s}$ & P-value \\
\hline Anthracene & 47 & 0.16 & 0.29 \\
Phenanthrene & 84 & 0.22 & 0.04 \\
1-Methylphenanthrene & 56 & 0.28 & 0.04 \\
2-Methylphenanthrene & 57 & 0.18 & 0.19 \\
3-Methylphenanthrene & 57 & 0.17 & 0.21 \\
9+4-Methylphenanthrene & 57 & 0.17 & 0.21 \\
Fluoranthene & 93 & 0.33 & 0.001 \\
Pyrene & 93 & 0.34 & 0.001 \\
2-Methylpyrene & 86 & 0.26 & 0.01 \\
1-Methylpyrene & 91 & 0.34 & 0.001 \\
4-Methylpyrene & 91 & 0.33 & 0.001 \\
Benzo(a)fluorene & 92 & 0.27 & 0.009 \\
Benz(a)anthracene & 93 & 0.36 & $<0.001$ \\
Chrysene/triphenylene & 91 & 0.35 & 0.001 \\
Benzo(a+b)fluoranthene & 93 & 0.29 & 0.004 \\
Benzo(j+k)fluoranthene & 93 & 0.34 & 0.001 \\
Benzo(e)pyrene & 93 & 0.33 & 0.001 \\
Benzo(a)pyrene & 92 & 0.31 & 0.002 \\
Perylene & 92 & 0.36 & $<0.001$ \\
Indenol(1,2,3-cd)pyrene & 93 & 0.27 & 0.009 \\
Picene & 89 & 0.30 & 0.004 \\
Benzo(ghi)perylene & 93 & 0.35 & 0.001 \\
\hline
\end{tabular}

Table 5. Correlations $\left(r_{s}\right)$ among the potroom workers between gaseous phase polycylic aromatic hydorcarbons (PAH) $\left(\mu \mathrm{g} / \mathrm{m}^{3}\right)$ in the respiratory zone during a full workday and 1-hydroxypyrene in urine ( $\mu \mathrm{mol} / \mathrm{mol}$ creatinine) sampled after work, during the same workday.

\begin{tabular}{lccr}
\hline PAH & $\mathrm{N}$ & $\mathrm{r}_{\mathrm{s}}$ & P-value \\
\hline Anthracene & 92 & 0.30 & 0.003 \\
Phenanthrene & 93 & 0.29 & 0.005 \\
1-Methylphenanthrene & 93 & 0.35 & 0.001 \\
2-Methylphenanthrene & 93 & 0.37 & $<0.001$ \\
3-Methylphenanthrene & 93 & 0.38 & $<0.001$ \\
9+4-Metylphenanthrene & 93 & 0.38 & $<0.001$ \\
Fluoranthene & 93 & 0.31 & 0.003 \\
Pyrene & 94 & 0.25 & 0.02 \\
\hline
\end{tabular}

Scand J Work Environ Health 1999, vol 25, no 1 
Table 6. 1-Hydoxypyrene concentrations in urine ( $\mu \mathrm{mol} / \mathrm{mol}$ creatinine) immediately before work, and PAH-DNA adducts $/ 10^{\circ}$ nucleotides in peripheral lymphocytes in potroom workers, with respect to usage of respiratory protection devices (filter masks and airstream helmets). (PAH = polycyclic aromatic hydrocarbons, $D N A=$ deoxyribonucleic acid)

\begin{tabular}{|c|c|c|c|c|c|}
\hline \multirow{2}{*}{$\begin{array}{l}\text { Frequency of use of } \\
\text { respiratory protection } \\
\text { devices }\end{array}$} & \multirow[t]{2}{*}{$N$} & \multicolumn{2}{|c|}{$\begin{array}{l}\text { 1-hydoxypyrene } \\
\text { in urine }\end{array}$} & \multicolumn{2}{|c|}{$\begin{array}{l}\text { PAH-DNA } \\
\text { adducts }\end{array}$} \\
\hline & & Median & Range & Median & Range \\
\hline Never & 49 & 3.76 & $0.07-13.8$ & 2.66 & $1.44-6.67$ \\
\hline $\begin{array}{l}\text { Sometimes } \\
\text { (1- } 89 \% \text { of the time) } \\
\text { Always }\end{array}$ & 29 & 3.72 & $0.63-26.6$ & 2.62 & $1.49-4.97$ \\
\hline ( $>90 \%$ of the time) & 20 & 2.44 & $0.49-5.71$ & 2.61 & $1.52-4.89$ \\
\hline P-value & & 0.06 & & 0.5 & \\
\hline
\end{tabular}

a The P-values refer to the changes in 1-hydoxypyrene in urine and PAH-DNA adducts, with respect to the frequency of use of respiratory protection devices (Joncheere-Terpstra's test)

Table 7. PAH-DNA adducts $/ 10^{8}$ nucleotides in peripheral lymphocytes of the potroom workers and the referents, with respect to smoking habits. (PAH = polycyclic aromatic hydrocarbons, DNA = deoxyribonucleic acid)

\begin{tabular}{|c|c|c|c|c|c|c|}
\hline & \multicolumn{2}{|c|}{ Potroom workers } & \multicolumn{3}{|c|}{ Referents } & \multirow[t]{2}{*}{ P-value ${ }^{a}$} \\
\hline & N Median & Range & $N$ & Median & Range & \\
\hline Smokers & 272.61 & $1.44-4.97$ & 11 & 2.52 & $1.63-6.88$ & $>0.5$ \\
\hline Nonsmokers & 612.62 & $1.49-6.67$ & 42 & 2.36 & $1.28-5.30$ & $>0.5$ \\
\hline All subjects & 882.62 & $1.44-6.67$ & 53 & 2.47 & $1.28-6.88$ & $>0.5$ \\
\hline P-value ${ }^{b}$ & $>0.5$ & & & $>0.5$ & & \\
\hline
\end{tabular}

a The P-values refer to the difference in PAH-DNA adduct levels between the potroom workers and the referents, in different smoking habit strata. (Mann-Whitney's U-test).

b The P-values refer to the differences in the PAH-DNA adduct levels with respect to smoking habits, for the potroom workers, the referents, and the total group (Joncheere-Terpstra's test).

\section{Discussion}

The potroom workers in the present plant were exposed to a hundred times higher airborne level of both total $\mathrm{PAH}$ and, for example, B[a]P, than occupationally unexposed referents. No direct comparisons of the exposure levels for total PAH can be made with previous studies due to differences in the techniques employed for the sampling and chemical analysis. The levels of B[a]P in air can, however, be used for this purpose. In the present investigation the median time-weighted average (TWA) $\mathrm{B}$ [a]P concentration in air was $1 \mu \mathrm{g} / \mathrm{m}^{3}$ for the potroom workers; this value is exactly half the Swedish occupational exposure limit. Some workers were, however, exposed to very high concentrations. The maximum TWA level was $23 \mu \mathrm{g} / \mathrm{m}^{3}$, which can be compared with the maximum level of $94 \mu \mathrm{g} / \mathrm{m}^{3}$ observed for potroom workers in another plant where the Söderberg vertical-stud production process was also used (11). The airborne exposure to PAH in the present study represents, however, an improvement as compared with the situation a few years earlier, when the median exposure level for $\mathrm{B}[\mathrm{a}] \mathrm{P}$ was $2.8 \mu \mathrm{g} / \mathrm{m}^{3}(21)$. Before that, the exposure levels have probably been considerably higher. In Canadian aluminum smelters, where epidemiologic studies have revealed increased risks for both lung and bladder cancer for the workers, the TWA levels for $\mathrm{B}[\mathrm{a}] \mathrm{P}$ in air have been estimated to have been $10-20 \mu \mathrm{g} / \mathrm{m}^{3}$ during the relevant time period $(2,3)$. According to a risk assessment model derived from these data, a mean $\mathrm{B}[\mathrm{a}] \mathrm{P}$ exposure of $1 \mu \mathrm{g} /$ $\mathrm{m}^{3}$ during a 40-year period would result in a slightly less than doubled relative risk for bladder cancer.

The urinary concentrations of 1-hydroxypyrene sampled in the morning were about 30 times higher among the potroom workers than among the unexposed referents. The median morning level of hydroxypyrene was only slightly, though significantly, lower than the median postshift level $(3.43$ and $4.31 \mu \mathrm{mol} / \mathrm{mol}$ creatinine, respectively). The most important explanation for this finding is the fact that the majority of the workers studied belonged to a shift working from 1400 to 2200 . Hence, to a large extent, the morning urine levels reflected the exposure during the previous evening shift.

In contrast to the finding for airborne $\mathrm{B}[\mathrm{a}] \mathrm{P}$, the postshift urine concentrations of 1-hydroxypyrene for the exposed workers had not decreased during the last few years (21). However, in the previous investigation, only 9 workers were studied. In addition, the results may indicate that, for pyrene, skin absorption is a more important route than inhalation. On the average the concentration of 1-hydroxypyrene in urine was higher after work than in the morning, before work. The interindividual change in excretion over the workday, was, however, substantial. One reason for this difference may of course be differences in how the respiratory protection devices were used. Another reason is probably that the urinary excretion of 1-hydroxypyrene during a certain workday reflects not only the $\mathrm{PAH}$ exposure during the same day but also exposures during preceding workdays. The excretion of 1-hydroxypyrene seems to be biphasic, a readily available part of the pyrene body burden having a half-time ranging from 6 to 35 hours and another having a much longer half-time (16 days) $(7,13)$. The importance of the long half-time is illustrated by the fact that none of the studied workers at another aluminum plant showed an increase in their urinary 1-hydroxypyrene concentration during a 5-day exposure period (26).

The absolute levels of urinary 1-hydroxypyrene among the unexposed referents also fits well with previous data $(27,28)$ verifying the lack of occupational PAH exposure within this group. We observed significantly higher urinary concentrations of 1-hydroxypyrene for smoking referents than for nonsmoking referents. This 
finding is in accordance with the results from most ( 7 , $19,21,29,30$ ), but not all (11) previous studies.

Among coke oven workers (7) and Norwegian aluminum (19) and electrode paste (30) plant workers, smokers had higher mean urinary 1-hydroxypyrene concentrations than nonsmokers than could be explained by the minor contribution of smoking observed among referents. These observations have led to speculations that it may have been caused by the fact that smokers use protection masks less frequently or that smoking modulates xenobiotic metabolism or it may have been caused by a tobacco-smoke-induced reduced ciliary clearance (19). Among the exposed potroom workers in our study, smoking habits did not, however, at all affect the 1-hydroxypyrene concentrations in urine. This finding is in accordance with the results of 3 previous studies on aluminum workers $(10,11,26)$, and a study on foundry workers with much lower urinary concentrations of 1-hydroxypyrene (31).

In workers from an electrode paste plant, the urinary 1-hydroxypyrene concentrations were inversely correlated with age, due to a decrease in the creatinine level in urine with age, but no correlation was seen with frequent use of protective masks (30). In contrast, we did not find any correlation between age and the urinary excretion of 1-hydroxypyrene, but we found, on the other hand, that workers who always used respiratory protection devices had somewhat lower concentrations of 1-hydroxypyrene in their morning urine than other workers.

We found statistically significant, but only moderately strong, correlations between the TWA values for various airborne PAH and the change in excretion of 1-hydroxypyrene in urine over the same workday. There are several reasons why stronger correlations should not be expected. First, apart from inhalation, skin absorption has proved to be an important route of exposure $(14,32)$. Second, the interindividual variation in the use of respiratory protection devices will affect the association negatively. Third, the relatively long biological half-time of pyrene and its metabolite 1-hydrdoxypyrene calls for longer sampling periods. In an aluminum smelter very strong correlations have been observed between average $\mathrm{PAH}$ levels in air during a workweek and an increased excretion of 1-hydroxypyrene during the same workweek (11).

In our study, the PAH-exposed workers had no increase in aromatic DNA adduct levels in peripheral lymphocytes when compared with the unexposed referents. These adducts encompass PAH adducts but also contain other types of unknown adducts apparently present in all humans (24). Among the 4 previous studies on aluminum and electrode paste plant workers, 2 showed no increase in DNA adducts by the postlabeling assay or by immunoassay $(19,30), 1$ showed an increase in 1 of the 2 aluminum plants as compared with blood donor referents by the postlabeling assay (16), and 1 detected an exposure-related increase in DNA adducts by the postlabeling assay (18). The last-mentioned study was the only one in which the urinary 1-hydroxypyrene levels correlated with the aromatic adduct levels (18). The exposures were high in all the workplaces studied and the postlabeling assay was similar; it is therefore unclear why the results differed. A similar discrepancy in DNA adduct results has been found also for coke workers extensively exposed to PAH. The levels of PAH in foundries and bus garages have been much lower than for potroom workers, but increased DNA adduct levels have nevertheless been observed (33). Variation in the size distribution of the inhaled particles may be a contributing factor to these apparently contradictory findings.

\section{Acknowledgments}

This work was supported by grants from the Swedish Council for Work Life Research, the Swedish Cancer Society, the Emil Andersson's Research Fund, the Medical Faculty at the Lund University, and Gränges Metall $\mathrm{AB}$.

The contributions of Helena Bergström, RN, Irene Godin, RN, Gunbritt Lundström, RN, Anna Vestala, RN, Ruth-Marie Mattsson, RN, Iris Gustafsson, Anita Wallin, Jan Johansson, and Dan Isling, MD, to the blood and urine sampling are greatly acknowledged. Stig Berggren, Bo Fernström, Urban Svedberg, and Stefan Pålsson gave important contributions to the sampling for airborne exposures. We also thank Anne-Marie Nilsson Hagelroth for performing the chemical analyses of airborne $\mathrm{PAH}$, and Margaret Rhén for performing the analyses of 1-hydroxypyrene in urine.

\section{References}

1. International Agency for Research on Cancer (IARC). Polynuclear aromatic compounds. Lyon: IARC, 1984. IARC monographs on the evaluation of the carcinogenic risk of chemicals to humans, vol 34 .

2. Armstrong BG, Tremblay CG, Cyr D, Thériault GP. Estimating the relationship between exposure to tar volatiles and the incidence of bladder cancer in aluminium smelter workers. Scand J Work Environ Health 1986;12:486-93.

3. Armstrong BG, Tremblay C, Baris D, Thériault G. Lung cancer mortality and polynuclear aromatic hydrocarbons: a case-cohort study of aluminium production workers in Arvida, Quebec, Canada. Am J Epidemiol 1994;139:250-62.

4. Rønneberg A, Langmark F. Epidemiologic evidence of cancer in aluminum reduction plant workers. Am J Ind Med 1992;22:573-90.

5. VanRooij JGM, Bodelier-Bade MM, Jongeneelen FJ. Estimation of individual dermal and respiratory uptake of polycyclic 
aromatic hydrocarbons in 12 coke oven workers. $\mathrm{Br} \mathrm{J}$ Ind Med 1993;50:623-32.

6. Jongeneelen FJ, Bos RP, Anzion RBM, Theuws JLG, Henderson PT. Biological monitoring of polynuclear aromatic hydrocarbons: metabolites in urine. Scand J Work Environ Health $1986 ; 12: 137-43$.

7. Jongeneelen FJ, van Leuwen FE, Oosterink S, Anzion RBM, van der Loop F, Bos RP, et al. Ambient and biological monitoring of cokeoven workers: determinants of the internal dose of polycyclic aromatic hydrocarbons. $\mathrm{Br} \mathrm{J}$ Ind Med 1990;47:454-461.

8. Zhao Z H, Quan WY, Tian DH, Urinary 1-hydroxipyrene as an indicator of human exposure to ambient polycyclic aromatic hydrocarbons in a coal-burning environment. Sci Total Environ 1990;92:145-54.

9. Jongeneelen FJ. Biological exposure limit for occupational exposure to coal tar pitch volatiles at cokeovens. Int Arch Occup Environ Health 1992;63:511-6.

10. Tolos WP, Shaw PB, Lowry LK, MacKenzie BA, Deng JF, Markel HL. 1-Pyrenol: a biomarker for occupational exposure to polycyclic aromatic hydrocarbons. Appl Occup Environ Hyg 1990;5:303-9.

11. Tjoe Ny E, Heederik D, Kromhout H, Jongeneelen F. The relationship between polycyclic aromatic hydrocarbons in air and in urine of workers in a Söderberg potroom. Am Ind Hyg Assoc J 1993;54:277-84.

12. Jongeneelen FJ, Anzion RBM, Leidekkers CM, Bos RP, Henderson PTh. 1-Hydroxypyrene in human urine after exposure to coal tar and a coal tar derived product. Int Arch Occup Environ Health 1985;57:47-55.

13. Jongeneelen FJ, Anzion RBM, Scheepers PTJ, Bos RP, Henderson Th, Nijenhuis EH, et al. 1-Hydroxypyrene in urine as a biological indicator of exposure to polycyclic aromatic hydrocarbons in several work environments. Ann Occup Hyg $1988 ; 32: 35-43$.

14. Jongeneelen FJ, Scheepers PTJ, Groenendijk A, van Aerts LAGMJ, Anzion RBM, Bos RP, et al. Airborne concentrations, skin contamination, and urinary metabolite excretion of polycyclic aromatic hydrocarbons among paving workers exposed to coal tar derived road tars. Am Ind Hyg Assoc J 1988;49:600-7

15. Burgaz S, Borm PJA, Jongeneelen FJ. Evaluation of urinary excretion of 1-hydroxypyrene and thioethers in workers exposed to bitumen fumes. Int Arch Occup Environ Health 1992;63:397-401.

16. Schoket B, Philips DH, Hewer A, Vincze A. P-postlabelling detection of aromatic DNA adducts in peripheral blood lymphocytes from aluminium production plant workers. Mutat Res 1991;260:89-98.

17. Kriek E, van Schooten JF, Hillebrand MJ, van Leeuwen FE, Den Engelse L, De Looff AJA, et al. DNA adducts as a measure of lung cancer risk in humans exposed to polycyclic aromatic hydrocarbons. Environ Health Perspect 1993;99:71-5.

18. van Schooten IF, Jongeneelen FJ, Hillebrand MJ, van Leeuwen FE, de Looff AJ, Dijkmans AP, et al. PAH-DNA adducts in $\mathrm{WBC}$ and 1-hydroxypyrene in the urine from aluminium workers. Cancer Epidemiol Biomarkers Prev 1995;4:69-77.

19. Øvreb $\emptyset$ S, Haugen A, Hemminki K, Szyfter K, Drabløs PA, Skogland M. Studies of biomarkers in aluminium workers occupationally exposed to polycyclic aromatic hydrocarbons. Cancer Detect Prev 1995;19:258-67.

20. Savela K, Hemminki K. DNA adducts in lymphocytes and granulocytes of smokers and nonsmokers detected by the ${ }^{32} \mathrm{P}$ postlabelling assay. Carcinogenesis 1991;12:503-508.

21. Levin JO, Rhén M, Sikström E. Occupational PAH exposure: urinary 1-hydroxypyrene levels of coke oven workers, aluminium smelter pot-room workers, road pavers, and occupationally non-exposed persons in Sweden. Sci Total Environ $1995 ; 163: 169-77$.

22. Östman C, Carlsson H, Bemgård A, Colmsjö A. On-line LC $\mathrm{GC}$ for the analysis of PAH in small sample volumes. Polycyclic Aromat Compd 1993;suppl 3:485-92.

23. Östman $\mathrm{C}$, Bemgård $\mathrm{A}$, Colmsjö A. On-line liquid chromatography - gas chromatography for automated clean up and analysis of polycyclic aromatic hydrocarbons. J High Resol Chromatogr 1992;15:437-43.

24. Hemminki K, Yang K, Rajaniemi H, Tyndyk M, Likhachev A. Postlabelling-HPLC analysis of lipophilic DNA adducts from human lung. Biomarkers 1997;2:341-7.

25. Yang K, Airoldi L, Pastorelli R, Restano J, Guanci M, Hemminki K. Aromatic DNA adducts in lymphocytes of humans working at high and low traffic density areas. Chem Biol Interact 1996;101:127-36.

26. VanRooij JGM, Bodelier-Bade MM, de Loof AJ, Dijkmans AP, Jongeneelen JF. Dermal exposure to polycyclic aromatic hydrocarbons among aluminium workers. Med Lav 1992;83:519-29.

27. Boogaard PJ, van Sittert NJ. Urinary 1-hydroxypyrene as biomarker of exposure to polycyclic aromatic hydrocarbons in workers in petrochemical industries: baseline values and dermal uptake. Sci Total Environ 1995;163:203-9.

28. Hansen AM, Molin Christensen J, Sherson D. Estimation of reference values for urinary 1-hydroxypyrene and alpha-naphtol in Danish workers. Sci Total Environ 1995;163:211-9.

29. VanRooij JGM, Veeger MMS, Bodelier-Bade MM, Scheepers PTJ, Jongeneelen F. Smoking and dietary intake polycyclic aromatic hydrocarbons as sources of interindividual variability in the baseline excretion of 1-hydroxypyrene in urine Int Arch Occup Environ Health 1994;66:55-65.

30. Øvrebø S, Haugen A, Fjedstad PE, Hemminki K, Szyfter K. Biological monitoring of exposure to polycyclic aromatic hydrocarbons in an electrode paste plant. J Occup Med 1994;36:303-10.

31. Omland $\varnothing$, Sherson D, Hansen ÅM, Sigsgaard T, Autrup H, Overgaard E. Exposure of iron foundry workers to polycyclic aromatic hydrocarbons; benzo(a)pyrene-albumin adducts and 1-hydroxypyrene as biomarkers for exposure. Occup Environ Med 1994;51:513-8.

32. Clonfero E, Zordan M, Venier P, Paleologa M, Levis AG, Cottica D, et al. Biological monitoring of human exposure to coal tar: urinary excretion of total polycyclic aromatic hydrocarbons, 1-hydroxypyrene and mutagens in psoriatic patients. Int Arch Occup Environ Health 1989;61:363-8.

33. Hemminki K, Dickey C, Karlsson S, Bell D, Hsu Y, Tsai W$\mathrm{Y}$, et al. Aromatic DNA adducts in foundry workers in relation to exposure, life style and CYP1A1 and glutathione transferase M1 genotype. Carcinogenesis 1997;18:345-50.

Received for publication: 15 April 1998 